\title{
Firms' Qualifications and Subcontracting in Public Procurement: An Empirical Investigation
}

\author{
Luigi Moretti* \\ University of Padova \\ Paola Valbonesi** \\ University of Padova \& NRU-HSE
}

Using a newly assembled dataset, we empirically investigate the effects of subcontracting on procurement auction prices in Italy. In this setting, the prequalifications required for firms aiming to bid on public contracts determine the firms' different subcontracting formats. We find that fully qualified firms in a position to choose whether to subcontract generally offer lower prices than partially qualified firms, which must proceed with mandatory subcontracts. This result indicates that the firms' voluntary arrangements tend to improve market performance, while imposed arrangements tend to worsen market performance, in the public procurement supply-chain. (JEL H57, L23, L24, D44)

\footnotetext{
*Senior Research Fellow at the Department of Economics and Management, University of Padova. Email: luigi.moretti@unipd.it.

**Associate Professor of Economics at the Department of Economics and Management, University of Padova and Research Professor at the National Research University Higher School of Economics (NRU-HSE). Email: paola.valbonesi@unipd.it.

We are particularly indebted to Stephen Martin for his helpful suggestions. We are grateful to the Editor and two anonymous referees for their valuable comments on the previous version of the paper. We also wish to thank Klenio Barbosa, Alessandro Bucciol, Andrea Camanzi, Decio Coviello, Ottorino Chillemi, Francesco Decarolis, Gianni De Fraja, Dakshina G. De Silva, Caterina Giannetti, Ricard Gil, Stefano Galavotti, Roberto Grandinetti, Elisabetta Iossa, Francine Laffontaine, Marco Pagnozzi, Giancarlo Spagnolo, Yossi Spiegel, Steve Tadelis, Piero Tedeschi, and Francesca Zantomio, as well as the participants at the International Conference on "Public procurement and sustainable growth", San Servolo (Venice, 20-21 October 2011); the International Conference "Contracts, procurement, and public-private arrangements", Paris (30-21 May 2012); the Workshop PRIN on "The new industrial policy and private-public interactions between firms and markets", Capri (5-6 July 2012); the XXXIX EARIE Conference, Rome (2-4 September 2012); the XXVII Jornadas of economia industrial, Murcia (13-14 September 2012); the Conference of the Italian Society of Economists (SIE), Matera (18-20 October 2012); the 2013 Conference of International Industrial Organization Society, Boston (17-19 May 2013); the Workshop on "Sustainable public procurement: research trends and new challenges", HSE-NRU Moscow (4-5 October 2013); and the Department's seminars in Padova (June 2012) and Pisa (April 2012) for their helpful comments and suggestions. We are also grateful to the Osservatorio sui Contratti Pubblici, AVCP (Filippo Romano, Alberto Zaino) and the Ufficio Appalti e Lavori, Regione Valle d'Aosta (Edmund Freppa, Marisa Covolo) for providing data. We gratefully acknowledge the financial support of the Italian Ministry of Education, University and Research (grant PRIN2006-2006130472 003) and the University of Padova (grant N. CPDA084881/08). All remaining errors are our own.
}

The Journal of Law, Economics, and Organization, Vol. 31, No. 3 doi:10.1093/jleo/ewv001

Advance Access published February 11, 2015

(C) The Author 2015. Published by Oxford University Press on behalf of Yale University. All rights reserved. For Permissions, please email: journals.permissions@oup.com 


\section{Introduction}

Subcontracting usually involves "a reallocation of production requirements among firms" (Kamien and Li 1990: 1354), a process that is part of a firm's strategic production planning. Many theoretical contributions have addressed the determinants of subcontracting versus vertical integration and, more generally, the determinants of the firm's boundaries based on transaction costs (Williamson 1985), property rights (Grossman and Hart 1986), and the knowledge-based view of the firm (Kogut and Zander 1992, 1996). Empirical research has provided several case studies that have documented how and when firms adopt subcontracting to efficiently organize production in different economic sectors. ${ }^{1}$

These theoretical and empirical contributions are all based on the firm's voluntary choice of internal/external sourcing. In public procurement, however, firms are often constrained by many rules that limit their decision-making abilities. What decisions should firms be allowed to make in production planning to efficiently execute a public contract? The answer to this question should impinge on the policy makers' design of public procurement procedures. Indeed, rigid rules might limit the firms' decisions regarding the supply chain and thus affect the efficiency of procurement transactions and overall social welfare.

Typically, the regulatory burden related to the decision to subcontract in the execution of public contracts can be explained by two main factors. First, public resources allocated through these procurement contracts are often specifically intended to be affirmative action policies that indirectly enhance the participation of disadvantaged business enterprises (DBEs) through subcontracting schemes. Second, highly regulated procedures are adopted to maintain fairness in the procurement transactions in order to prevent favoritism, collusion, corruption, and/or poor performance.

Concerning the first factor, empirical evidence of the effect of rules requiring the participation of DBEs as subcontractors on the procurement costs is by no means conclusive. ${ }^{2}$ Marion (2009) exploited a modification of the Californian law that eliminated a preferential treatment policy and found that the average price of procured items fell by $5.6 \%$ in the state's Department of Transportation contracts. De Silva et al. (2012) empirically investigated the effect of a subcontracting goal program in Texas and compared projects in which prime contractors were obliged to outsource

1. A seminal empirical survey on the firms' vertical arrangements versus spot market transactions and long term contracts in different sectors has been proposed by Joskow (1988); more recently, Lafontaine and Slade (2007) have provided a thoughtful empirical survey on backward and forward vertical integration. Several case studies specifically investigate outsourcing in different sectors; see, among others, Novak and Stern (2008) and Macher (2006) on the automobile and semiconductor industries, respectively. Finally, for a discussion on core competencies and activities that are better performed externally, see Quinn and Hilmer (1994).

2. DBE programs are also implemented as bid preference schemes or set-aside auctions for such business (Marion 2007; Krasnokutskaya and Seim 2011; Athey et al. 2013). 
a portion of their contracts to DBEs with projects in which they were not obliged to do so; they found little differences between the projects in the level of submitted bids. ${ }^{3}$

Concerning the second factor, relevant examples are provided by frameworks for supplier qualification screening, which typically aim to verify that the supplier is indeed able to comply with all of the contract specifications with a reasonable degree of certainty. In this aim, supplier qualification screening often involves the verification of a firm's financial status, references, product, and surge capacity. These procedures determine a firm's entry into the public procurement market and, according to the adopted rules and verification criteria, can directly affect the supplier's make-or-subcontract choice when executing a contract. Although supplier qualification screening is commonly used in many countries, it is surprising that so little has been written about the effects of such procedures on the procurement costs. ${ }^{4}$ To the best of our knowledge, no empirical work has investigated how the rules regarding firm qualification screening affect the subcontracting and, hence, the public contracts in terms of both prices and performed quality. ${ }^{5}$ This dearth of research is surprising, considering that public procurement accounts for approximately $15 \%$ of the GDP in developed countries. Thus, given the size of the market, it is necessary to have a clear understanding of the best rules that foster the contractors' ability to make efficient supply-chain decisions. ${ }^{6}$

This article aims to help fill this research gap. We empirically investigate the Italian regulations concerning qualification screening for public works that determine two different positions regarding a firm's decision to subcontract or not. Similar to regulations in other national procurement settings, ${ }^{7}$ the Italian regulations for public works require that: (1) suppliers undergo a preliminary qualification screening before they enter the public contract market, and (2) every task in public contracts be

3. As suggested by De Silva et al. (2012), these contrasting results can be driven by the very different environments that the two studies focused on.

4. Experimental and theoretical studies comparing costly ex-ante or ex-post qualification screening in procurement have been recently provided by Wan et al. (2012) and Wan and Beil (2009).

5. Conversely, a conspicuous number of empirical contributions have investigated which auction format should be addressed by procurement regulation to promote lower awarding prices and better contractual performances. See, among others, Bajari et al. (2009), Decarolis (2013), Bucciol et al. (2013), Lewis and Bajari (2011), and Olivares et al. (2012).

6. The recent "Green Paper on the modernization of EU public procurement policy" (2011) indicates that subcontracting is a relevant tool to encourage the participation of small and medium enterprises (SMEs) in public procurement contracts, whereby SMEs are considered to be of crucial importance for stimulating job creation, economic growth, and innovation. However, no recommendations for best practices are provided.

7. Qualifications are needed to enter the market for public contracts in many EU countries, the United States, and Japan; however, the design of these systems and the criteria adopted differ somewhat. For a few detailed examples, see OECD (2007). 
completed by qualified suppliers. Specifically, these requirements affect a firm's make-or-subcontract decision in two ways:

- if the firm is not qualified to complete all of the tasks in a given contract, its production strategy has to take into account a "mandatory subcontracting" agreement with another firm that is qualified to do so;

- if the firm is fully qualified to complete all of the tasks in a given contract, its production strategy may or may not involve subcontracting for part of the work to a similarly qualified firm; and, in this case, the firm holds an "optional subcontracting" position.

Thus, qualified firms bid for each tendered public contract with the advance knowledge that they are either in a position to opt for subcontracting or required to do so once they win the contract. Our aim is to test whether these subcontracting positions are likely to affect a firm's bid and thus to determine different procurement costs. We also control for the effects of optional and mandatory subcontracting on ex-post contract performance; that is, the probability of time and cost overrun.

The data. We have assembled an original dataset containing information on the Italian public procurement contracts awarded by open tender and the characteristics of the bidding firms. For each tendered contract, we specifically collected information regarding the tasks to be completed (i.e., the "categories of work" corresponding to the qualifications required), the identity and the qualifications of the bidding firm. Thus, by matching the qualifications that are required to execute a contract with each bidder's qualifications, we are able to identify the bids that are offered by partially qualified firms (i.e., firms that will have to engage in mandatory subcontracting if they win the auction) and by fully qualified firms (i.e., firms that may choose to complete the project by themselves or to use subcontractors).

Our identification and results. We adopted a reduced-form approach and control for auction/contract-related characteristics and for firm characteristics and fixed effects. In fact, our identification relied on the withinfirm variability of the subcontracting position when bidding for different contracts. In our sample, most of the bids (74.7\%) were offered by firms that had taken part both in auctions where they had an optional subcontracting position and in auctions where they had a mandatory subcontracting position. This approach allowed us to reduce the omitted variables problem and to limit differences in the types of firms that adopted optional or mandatory subcontracting. Furthermore, in our aim to better capture the firm characteristics that can also vary over time, in different specifications of the model we controlled for the firmyear-fixed effects, which allowed us to focus on the within-firm and firmyear variations in the subcontracting positions.

Our empirical results show that bidding firms in a position to choose whether to subcontract part of the work (i.e., optional subcontracting) 
offer lower prices than those obliged to subcontract part of the work (i.e., mandatory subcontracting). This effect is still significant when we focus on the sub-sample of bids offered by winning firms that actually did engage in subcontracting. These findings indicate that the production efficiency derived from subcontracting is higher when it is an option and not an obligation for the firm concerned to perform its activities externally. ${ }^{8}$ In other words, mandatory subcontracting, which is an induced practice arising from regulation that restricts a firm's supply chain, tends to increase procurement costs. We argue that these results are explained by the interplay of the following factors. If a firm can choose to subcontract, it will do so only if subcontracting is profitable. In this case, subcontracting also implies that firms outsource part of the work to "similar and known" firms and this entails lower search costs, as well as greater information symmetry concerning the execution costs. Moreover, being able to choose whether to outsource some of the works and having greater information symmetry together generate for the contractor stronger bargaining power in optional than in mandatory subcontracting transactions.

Related Literature. This article provides three main contributions. First, it contributes to the recent empirical literature on subcontracting in public procurement that has investigated which rules and/or factors lead to both cost efficiency and quality in the execution of outsourced contracts. As already discussed, De Silva et al. (2012) and Marion (2009) focus on the procurement costs of programs supporting subcontracting in favor of specific groups of firms. Miller (2014) considers the impact of the complexity and incompleteness of construction contracts on subcontracting versus in-house arrangements. Gil and Marion (2013) examine the effect of past and future relationships between contractors and subcontractors in enforcing informal agreements and the effect of these relationships on the firms' bid and entry decisions in the procurement of California highway contracts. Marion (2012) estimates the effect of horizontal subcontracting on bidding strategies in auctions conducted by the California Department of Transportation and highlights the factors that lead to this type of outsourcing. As an original contribution to this literature, we add an empirical analysis of procurement price and performance in a setting where rules from supplier qualification screenings affect the firms' subcontracting positions and thus the available alternatives regarding make-or-subcontract decisions.

Second, our article contributes to the extensive economics literature on firm boundaries originating from Williamson's (1971) influential work on transaction costs. In this respect, we specifically offer an empirical test for the effect of horizontal and vertical sourcing on the firm bidding for public

8. In a competitive stochastic investment game, Van Mieghem (1999) investigates the firms' choice of subcontracting as an option value and finds that the choice of subcontracting improves the firms' financial performance and investment coordination under a high degree of uncertainty. 
works contracts. 9 "Horizontal" subcontracting is defined in Spiegel (1993) as an agreement between rival firms where "each of which is capable of producing and marketing its product independently", while "vertical" subcontracting is an agreement between firms with complementary capabilities/assets that aims to obtain an output (Webster et al. 1997). In our setting, optional subcontracting can be considered a horizontal agreement, as it occurs between similarly qualified firms, while mandatory subcontracting can be considered a vertical agreement, as it corresponds to an agreement between firms with different qualifications/capabilities. Comparing bids by firms in optional or mandatory subcontracting positions, we find that optional subcontracting promotes productive efficiency. Note that our results are consistent with Lafontaine and Slade's (2008) findings from an empirical survey on vertical restraints. These authors conclude that, when manufactures choose to impose vertical restraints, their impact on market performance is positive by implication and if vertical restraints are prohibited, then the impact is negative. Our empirical findings on subcontracting and Lafontaine and Slade's findings on vertical restraints both highlight the fact that, on the one hand, the firms' voluntary arrangements tend to improve market performance but, on the other hand, any imposed arrangements that either prohibit or mandate relationships tend to worsen market performance.

Third, our article provides empirical evidence regarding the cost arising from procurement rules that limits the discretion of the agents (both the supplier and the contracting authority [henceforth, CA]) in procurement transactions. There is a lively debate about the optimal regulation of public contracts through the use of more rigid or more flexible rules affecting the procurement transaction outcomes. Spagnolo (2012) highlighted that this debate directly refers to the inclusion of reputational forces and arises from two opposite positions. In Europe, regulation has constrained the use of past performance information to select contractors, while in the United States, the establishment of databases to evaluate the companies' past performance in public contracts and to share this information has been encouraged. Specifically referring to the framework for supplier qualification screenings, this article adds an empirical test for the cost of a planning constraint (i.e., mandatory subcontracting) in the firms' strategy regarding a contract's execution. Future research is needed to assess the cost of both flexible and rigid rules in procurement, and to design an appropriate balanced mechanism.

The structure of the article. The remainder of this article is organized as follows. Section 2 describes the institutional features of public procurement auctions and subcontracting in Italy. Section 3 gives detailed information about the datasets on which we base our investigations. Section 4 presents the econometric model, empirical results, and robustness tests,

9. Theoretical contributions on horizontal subcontracting have been provided by Kamien et al. (1989), Gale et al. (2000), and Spiegel (1993). 
considering all of the firms' bids. Section 5 illustrates the results of our estimations when we focus on the bids offered by the winning firms; that is, the firms that won and fulfilled the contracts. Section 6 presents our findings on the measures of ex-post performance. Conclusive comments are given in Section 7.

\section{Regulation on Entry into the Italian Procurement of Public Works}

In this section we briefly review the regulation on the supply and demand sides of the Italian market for the procurement of public works, focusing on the rules that directly affect the firms' subcontracting positions. We also provide a brief description of the adopted auction format.

The supply side. According to Italian law on public procurement, firms must prequalify to bid in auctions for public work contracts worth more than 150,000 euros. ${ }^{10}$ The Italian system for qualifying firms is operated by a third party (i.e., 37 private companies, called "Societa' Organismi di Attestazione" [SOA]) that is accredited and monitored by the authority in charge of regulating the national market for public works, supplies, and services ("Autorita' di Vigilanza sui Contratti Pubblici di Servizi, Lavori e Forniture" $\left.[\mathrm{AVCP}]^{11}\right)$. The firms' qualifications are provided after established "general" and "technical" attributes have been ascertained by a SOA. The general attributes concern the firms' financial standings and criminal records (e.g., anti-Mafia) and these attributes are the same for any firm wishing to participate in an auction for the procurement of public works. The technical attributes have to do with the specific skills that are needed to perform certain works and are usually assessed based on the firms' documented expertise and other observable items. Specifically, the Italian procurement regulation defines 46 "categories of work" under which firms can qualify for consideration for a period of 3 or 5 years before their qualifications must be renewed.

The costs of a firm's choice to get qualified to enter the market for public works can be decomposed into i) an investment cost to gain the capabilities necessary for each specific qualification and ii) an administrative cost to comply with the required procedures. The latter cost, which consists of a fee (resulting decreasing in the number of categories of work that the firm qualifies for), some formal documents, and the time taken to carry out these procedures, is low compared to the advantages for the firm when it repeatedly wins public contracts. ${ }^{12}$ The former cost, which refers to the acquisition of firm technologies, capabilities, and expertise required to qualify for each category of work in the public procurement process, is large and requires specific medium and long-term investments.

10. See: Italian Law No. 163/2006.

11. Since August 2014, AVCP is part of the Italian National Anti-Corruption Authority (ANAC).

12. Note that the certification body (SOA) charges an extra fee if a qualified firm asks to delete a previously obtained qualification or add a new qualification. 
According to the stakeholders, qualified firms tend to maintain the same qualifications from year to year in order to maximize the probability of recovering their investment costs by becoming a main contractor, subcontractor, or member of a consortium in the execution of public works.

The demand side. A large part of the Italian public procurement market consists of contracts that are typically awarded by local CAs (i.e., municipalities, provinces, regions). ${ }^{13}$ When awarding a contract, the CA should specify all the tasks (the categories of work) and distinguish between the main and secondary categories of work that are included in the project. For example, consider a contract for the building of a road in a new residential area. The fulfillment of this contract involves three tasks: $t_{A}$ (road works), $t_{B}$ (water works), and $t_{C}$ (sewage works). Accordingly, in the call for tenders, the CA will present task $t_{A}$ as the main category of work and the remaining two tasks $\left(t_{B}\right.$ and $\left.t_{C}\right)$ as the secondary categories of work. This distinction is relevant, as participation in the tender process is restricted to firms that are qualified for the main work category. Alternatively, firms that are not qualified for the main work category can participate in the auction as part of temporary consortia (called "Associazioni Temporanee d'Impresa" [ATI]). These consortia are created ad hoc to bid for a given contract and involve at least one firm that is fully qualified for the main task. $^{14}$

For the secondary categories of work involved in a public contract up for tender, the bidding firm may either be qualified or not. If a firm is qualified, the firm winning the contract can choose either to complete all of the works on its own or to subcontract parts of the works to other similarly qualified suppliers (i.e., giving rise to optional subcontracting). On the other hand, if a firm is not qualified for one (or more) of the secondary categories, it can still bid for the contract, but it will have to subcontract the works, where it lacks the necessary qualifications, to other qualified firms (i.e., mandatory subcontracting). ${ }^{15}$

Considering optional and mandatory subcontracting in terms of firm integration, the former type of subcontracting can be interpreted as horizontal outsourcing because it occurs between two similarly qualified firms.

13. According to the 2013 AVCP Annual Report, approximately $63 \%$ of contracts in 2011, with a value of 1160 million euros, were awarded by local governments.

14. We can reasonably assume that consortia bidding for tendered contracts are qualified to perform all the categories of work involved in a project, as each consortium is established ad hoc for a tendered contract. Note that in our dataset, bidding behavior is not (statistically) different between consortia and firms in an optional subcontracting position; this evidence holds even when auction and firm characteristics are controlled for.

15. As a remote alternative, the firm can lease the qualification for a task for which it lacks qualifications from a qualified firm that is not bidding for the contract. This is a rarely used practice because it entails a very expensive agreement (called "avvalimento"). Note that the supplier can also subcontract part of the main category of work but cannot subcontract more than $30 \%$ of the category's value. This is a not widely adopted practice and, according to our definition, it corresponds to optional subcontracting, as the bidder should be qualified for the main task in order to participate in the auction. 
The latter type of subcontracting corresponds to the required vertical outsourcing because it occurs between two firms with complementary capabilities.

The auction format. In the Italian procurement of public works, qualified firms participate by offering a bid consisting of a percentage reduction - a rebate - on the reserve price set by the CA. The most widely adopted auction format is based on an average bid auction (ABA) in which the winner is determined as follows. Given the distribution of all bids received in an auction, a first average (A1) is computed by averaging all the bids, except those located in the first and last deciles. A second average (A2) is then computed by averaging all of the bids above A1 (again, excluding those bids located in the last decile). The winning bid is the one immediately below A2 (see Figure B1, upper panel, in Appendix B for an illustration). ${ }^{16}$

The essential theoretical prediction of a general ABA format (where all bids are considered and the one closest to the average wins) is that all bidders have an incentive to submit identical bids, leading to a potential continuum of Nash equilibria in which all firms submit the same bid at a price that is high enough to ensure profitability for all bidders. Empirical and theoretical research on ABA indicates that prices should be higher than those found using a first-price format and that the random selection of a winner could diminish performance (see Albano et al. 2006, and Decarolis 2013). Recent experimental research comparing ABA and first-price auctions indicates that bids in both formats are "strongly influenced by cost signal" and that "there is no statistically significant difference in bidding behavior" between the two formats (Chang et al. 2013: 13 and 11 , respectively). This experimental evidence on bidding behavior, coupled with the ABA rule that awards the contract to the (somehow defined) average bid, seems to support the CAs' repeated adoption of ABA in the procurement of public works. In some countries, this is deemed to be a reasonable mechanism to adequately compensate suppliers and avoid supplier defaults.

Summary. The aim of the Italian system for firms' qualifications is to restrict auction participation to firms that are capable of executing the contract's main category of work with a reasonable degree of certainty. For the secondary categories of work involved in a tendered project, firms may or may not be fully qualified. In the latter case, firms are obliged to subcontract the work to qualified firms, as all aspects of the project must be handled by qualified firms.

16. In the awarding phase, bidding firms observe a reserve price that is computed by the CA using various formulas that typically overestimate contractual costs, thus resulting in an ineffective binding. Note also, if there are fewer than 10 bidders the lowest and highest bids are not considered when computing the first average (A1); if there are fewer than five bidders, the project is awarded to the firm that has offered the highest rebate. In our sample of 269 auctions, only one auction has fewer than five bidders and nine have fewer than ten bidders. 
A noteworthy direct consequence of this public procurement regulation is that, when a contract is tendered, the potential position of each bidder concerning any subcontracting is well defined, as the categories for which the bidding firms should be qualified are also announced. This means that each firm bidding for a public contract is aware that, if it wins, it may outsource some of the tasks for which it is fully qualified or it will be obliged to subcontract certain tasks for which it is not qualified. Thus, the regulation on bidder qualifications for public contracts allows firms to assess their own production strategy at the bidding stage. This process permits us to observe the two subcontracting formats and, accordingly, the firms' bids. For the sake of our analysis, it is important to bear in mind that, within the framework we are investigating, the same bidder may be in a position to adopt optional subcontracting for some auctioned contracts, but mandated subcontracting for some other contracts.

\section{Data}

Different data sources were used to assemble our original dataset for the purposes of the present analysis. Detailed information on each open tendered public contract has been taken from a hitherto unexploited dataset, consisting of the transcripts of competitive auctions conducted from 2000 to 2008 by the Regional Government of Valle d'Aosta (the CA). ${ }^{17}$ Each transcript contains information on the auction ID, number of bidders, bidders' names, and bids. The auction ID enabled us to access other details of the tendered contracts from a national dataset managed by the AVCP, containing all the contracts with a reserve price higher than 150,000 euros. This dataset includes information on the contract awarding procedure, the reserve price of the contract, the categories of work involved in the contract, and the final price paid by the CA and the timing for the completion of the project.

Information on the suppliers' qualifications was extracted from another national AVCP dataset known as the "Casellario SOA", a kind of national register that collects the qualification status of every firm for each work category.

In summary, for each tendered contract, we have information on the qualifications that are required to complete the tasks involved in the contract and all of the actual qualifications held by each bidding firm. Matching these data enabled us to disentangle the firm bids in an optional subcontracting position that would have the choice to subcontract from the firm bids that would be obliged to proceed with a mandatory subcontract for part of the project.

17. Valle d'Aosta is a small mountainous region ( $3263 \mathrm{sq} \mathrm{km}, 951 \mathrm{MSL}$ ) with a population of 129,000 on Italy's northwestern border with France and Switzerland. 


\subsection{Descriptive Statistics}

Our dataset consists of public contracts that were awarded by the Regional Government of Valle d'Aosta by means of open tenders. ${ }^{18}$ Once the CA acquired the bidders' qualifications regarding legal, fiscal, economic, financial and technical requirements, the contract was awarded according to the ABA. In the setting we investigated, this auction format was used for $89.2 \%$ of the auctions in our sample. For the remaining $10.8 \%$, a similar average bid mechanism was combined with a type of lottery to determine the winning bid. ${ }^{19}$

Our dataset covered 269 auctions for public contracts, where a total of 13,331 prices were offered by bidders consisting of 892 firms and 1777 temporary consortia. ${ }^{20}$ The average reserve price was approximately 1.1 million euros (ranging from 156,000 to 5.3 million euros). In terms of the various tasks, these contracts represented mainly road works $(37.2 \%)$, river and hydraulic works $(29.7 \%)$, and buildings $(14.9 \%)$; see Table 1 where further summary statistics are also included.

As shown in Table 2, 73.8\% of the bids in our sample were offered by firms that had all the necessary qualifications and could therefore opt to horizontally subcontract part of the work, while $12.9 \%$ of the bids were offered by firms that were not qualified for some of the secondary categories of work and would therefore be obliged to subcontract some work to other qualified firms. Finally, approximately $13.3 \%$ of the bids were offered by consortia.

In our sample each firm participated in about five auctions (13 auctions if we exclude consortia), on average. As previously noted in Section 2 (about the supply side), firms tend to maintain their qualifications from one year to the next, leading to different firm subcontracting positions in different contracts. Given each firm's qualifications, we observe that each firm's subcontracting position varies according to the tasks included in the

18. According to EU directives, public procurement in Italy can take place through four types of awarding procedures: open, restricted, negotiated, and competitive dialogue. In our study, we consider only those cases involving open tenders (the so-called "pubblico incanto"). Participants in restricted and negotiated tenders are invited by the CA, so including such cases in our analysis may bias our results because the CA could invite firms with particular features and qualifications. We have no data concerning contracts awarded using competitive dialogue procedures.

19. This auction format works as follows: Given A2 computed as above, a random integer $\mathrm{R}$ between 1 and 9 is extracted. The R-th number among the nine equidistant numbers between the bid just above the first decile and the bid just below A2 is averaged with A2 to obtain the winning threshold. The winning bid is the bid immediately above this winning threshold. We define A3 as the winning threshold that results when $\mathrm{R}=1$ (see Figure B1, lower panel, in Appendix B). As shown in Galavotti et al. (2014), the mean rebate is lower in the ABA format that is combined with a type of lottery than in the other ABA format; however, the bidding behavior is similar in both formats.

20. Note that the total number of original bids for these 269 auctions was approximately $10 \%$ higher. However, for this share of bids, we do not have information on the bidders' qualifications, so these bids were not considered in our final sample of 13,331 bids. 
Table 1. Descriptive Statistics: Bidding Offers and Contract Characteristics

Procurement projects issued by Valle d'Aosta Regional Government

\begin{tabular}{lrrrrr}
\hline Variable & Obs. & Mean & St.Dev. & Min & Max \\
\hline Bid (Rebate, in \%) & 13331 & 17.210 & 4.831 & 0.001 & 43 \\
Reserve price (euros) & 269 & 1103786 & 865298.5 & 155526.3 & 5267860 \\
No. of participants & 269 & 55.450 & 31.845 & 3 & 155 \\
Expected duration (days) & 269 & 311 & 168.179 & 79 & 1440 \\
ABA & 269 & 0.892 & 0.311 & 0 & 1 \\
ABA + lottery & 269 & 0.108 & 0.311 & 0 & 1 \\
Road works & 269 & 0.372 & 0.484 & 0 & 1 \\
River and hydraulic works & 269 & 0.297 & 0.458 & 0 & 1 \\
Building & 269 & 0.149 & 0.356 & 0 & 1 \\
\hline
\end{tabular}

Note: See Appendix A for the definitions of the variables.

Table 2. Descriptive Statistics: Bidders' Characteristics

\begin{tabular}{lc}
\hline & Percentage \\
\hline Local bidders (\% of bids) & 32.37 \\
Bidders' size (\% of bids): & 11.80 \\
small & 52.86 \\
medium & 22.01 \\
large and co-operatives & 13.33 \\
Consortia (\% of bids =\% of bidders) & \\
Subcontracting status (\% of bids): & 12.86 \\
Mandatory & 73.81 \\
Optional (excluding consortia) & 1.40 \\
Subcontracting status (\% of bids): & 74.72 \\
Always mandatory firms & 10.55 \\
Sometime optional and sometime mandatory firms & \\
Always optional firms (excluding consortia) & \\
\hline
\end{tabular}

Note: See Appendix A for the definitions of the variables.

contract. In our sample, approximately $74.7 \%$ of the bids were offered by firms that took part both in auctions where they had an optional subcontracting position and in auctions where they had a mandatory subcontracting position. Approximately $23.9 \%$ of the bids were offered by firms (including consortia) that always had an optional subcontracting status and approximately $1.4 \%$ of the bids were by firms that were always committed to adopting mandatory subcontracting.

The descriptive statistics for our sample gives us a clear idea of the local dimensions of the market for procuring public works in Valle d'Aosta (see Table 2). Approximately 35.3\% of the participants in the auctions (corresponding to $32.4 \%$ of the bids) were firms located in the region, and $22.6 \%$ of the participants $(27.6 \%$ of the bids) were firms from the larger 
neighboring Piedmont region. The remaining $42.1 \%$ of participants (40.0\% of the bids) came from other parts of Italy. The average distance between the bidder's location (i.e., the closest capital city) and the CA location (i.e., the city of Aosta) was approximately $310 \mathrm{~km}$ (with a standard deviation of $399 \mathrm{~km}$ ). In terms of the prices offered, local firms offered an average discount of $17.0 \%$, which was slightly lower than the mean discount of $17.3 \%$ by non-local firms. Similarly, the backlog of projects (i.e., the number of ongoing public projects each firm has at the time of bidding) was lower for the local firms (1.1 projects) than for the other firms (2.8 projects). ${ }^{21}$

\section{Analysis of the Bidding Offers}

\subsection{Testable Hypothesis and Model Specification}

In this section, we consider the bids offered by all of the participating firms in the 269 auctions for the procurement of public contracts. We consider the bid as a proxy for the value attributed by the firm to the project; that is, what the firm expects the work to cost, plus a mark-up. We reference our approach to the recent experimental findings by Chang et al. (2013), who compared the first-price (i.e., "low bid") and "average bid" methods, and found that bidding behavior is identical in the two formats and strongly influenced by cost signals. Accordingly, we simply assume in this study that the bid is a proxy for each firm's expected costs to complete the tendered contract. ${ }^{22}$

Mandatory and optional subcontracting in this procurement setting can be considered a planning constraint and a planning alternative, respectively, in the firms' strategy regarding the contract's execution, and consequently, with different effects on the expected cost and, therefore, the firms' bids. Our testable hypothesis is that there may be a significant difference between firms who are obliged to subcontract and firms who are in a position to complete the contracted work themselves or outsource part of the work.

A simple two-group mean-comparison test (Table 3) shows that the average rebates offered by firms obliged to subcontract are significantly lower (i.e., corresponding to higher prices to be paid by the CA) than those offered by firms with the option to subcontract. The picture does not change after we exclude the consortia from the sample.

21. The distance is defined as the number of kilometers between the capital city of the supplier's province and the city of Aosta (i.e., the capital city of the single-province region of Valle d'Aosta). The firm backlog is defined as the number of pending projects (also considering the public procurement works tendered in the other Italian regions) the firm had at the date of bidding. Because we do not have data on firm size, we use the type of business entity as a proxy; approximately $75 \%$ of the bids were offered by medium and large firms. See Appendix A for detailed definitions of the variables.

22. Bajari et al. (2014) empirically investigate highway procurement in the State of California and show that adaptation costs are an important determinant of the firms' bids in public procurement, accounting for $8-14 \%$ of the winning bids. 
Table 3. Correlation: Subcontracting Status and Bidding Offers

\begin{tabular}{lll}
\hline & Mean rebate & Mean rebate (excluding consortia) \\
\hline Optional & 17.348 & 17.339 \\
Mandatory & 16.272 & 16.272 \\
Difference & $1.076^{\text {** }}$ & $1.067^{\text {** }}$ \\
\hline
\end{tabular}

Note: See Appendix A for the definitions of the variables.

Inference: ${ }^{\star \star \star} p<0.01,{ }^{\star *} p<0.05,{ }^{*} p<0.1$.

These results may be due to various factors associated with the characteristics of the firms and auctions concerned. For instance, larger and/or more efficient firms may be more likely to be fully qualified because they are qualified for a larger number of categories of work. To check for the influence of these factors and to examine the differences in the price offered by bidders in the two subcontracting positions, we estimate the following model specification for bidding rebates:

$$
\text { Rebate }_{i j}=\alpha+\beta \text { Optional }_{i j}+\gamma Q_{j}+\theta X_{i}+\lambda Z_{i j}+\epsilon_{i j}
$$

where Optional is a dummy variable with a value of 1 when firm $i$ is fully qualified to handle project $j$ 's tasks (i.e., in an optional subcontracting position) and a value of 0 when the firm is partially qualified (i.e., in a mandatory subcontracting position). $Q_{j}$ is a set of variables that controls for the nature of the project and auction (i.e., proxies for the characteristics of the project, such as its dimension or complexity and type of work involved; proxies for the characteristics of the auction, such as the format and the level of competitive pressure; and year dummy variables to adjust for temporal shocks that may have affected both the time-related trends of the firms' bidding behavior and the contracts chosen by the CA). $X_{i}$ represents a set of firm characteristic features (i.e., proxies for firm size and the distance between the firm location and CA). $Z_{i j}$ controls for the firm's capacity constraints, which is proxied by a measure of the firm's backlog when it bids for a project, and $\varepsilon_{i j}$ is the error component.

In some model specifications, to reduce the omitted variable problems, we include firm-fixed effects to adjust for firm-specific characteristics (e.g., size, productivity, financial position, and location). This enables us to focus on the within-firm variation in optional or mandatory subcontracting status and to capture the effect of changes therein better. These firm-specific characteristics could also vary over time, so in different specifications of the model we include firm-year-fixed effects to focus on the within-firm-year variations in the subcontracting positions.

\subsection{Estimation Results}

Our primary coefficient of interest is $\beta$, which indicates whether a firm's subcontracting status affects its bidding offer. This coefficient reflects the 
difference between the rebates offered by firms that can choose to subcontract and the rebates offered by those obliged to subcontract. To address potential heteroscedasticity issues, we use ordinary least squares (OLS) estimates with robust standard errors clustered at the firm level to enable correlations among within-firm observations.

Our results are presented in Table 4, columns 1-3, and show that the coefficient for the Optional variable always has a positive sign and is statistically significant. ${ }^{23}$ All else remaining equal, firms that are fully qualified to complete a project and, thus, may or may not subcontract part of the work, offer significantly greater rebates (i.e., corresponding to lower prices) than firms that are obliged to subcontract part of the work to other qualified firms. In particular, fully qualified firms offer discounts approximately 0.3 percentage points larger than partially qualified firms. This value corresponds to about $2 \%$ of the average bidding discount observed in our sample.

These findings show that a bidding firm's production efficiency increases (i.e., via lower production costs) when its subcontracting position is flexible and this enables the firm to subcontract part of the project to similar firms. This is not the case when firms are required to subcontract part of the work to other complementary firms.

We interpret our findings from the following considerations. If a firm can choose to subcontract, it will do so only if subcontracting is profitable. ${ }^{24}$ Optional subcontracting implies that firms outsource part of the work to "similar and known" firms; thus, optional subcontracting is associated with lower search costs, as well as greater information symmetry concerning the execution costs, than any form of required subcontracting to firms with "different and complementary" qualifications. Moreover, being able to choose whether to subcontract part of the work and to have greater information symmetry combined to give a firm stronger bargaining power in optional compared to mandatory subcontracting.

These considerations are based on several studies of the effect of the parties' information asymmetry and bargaining power on the outsourcing choice. For the effects of information asymmetry, Lewis and Sappington (1991) use a standard procurement model and assume that firms are better able to monitor effort in their internal tasks rather than in outsourced tasks. Because the subcontractor may have a lower cost technology, the

23. Note that, in Table 4, column 1, we estimate our full sample of bidding rebates; in column 2 we include firm-fixed effects and focus on the bids offered by firms that we observe more than once and took part both in auctions where they had an optional subcontracting position and in auctions where they had a mandatory subcontracting position; while, in column 3, we include firm-year-fixed effects and focus on the bids offered by firms that we observe more than once in a given year and took part both in auctions where they had an optional subcontracting position and in auctions where they had a mandatory subcontracting position in a given year.

24. Quinn and Hilmer (1994) present an extended discussion on the firms' relative risks/ costs and benefits from outsourcing in different industrial sectors. 
Table 4. Estimation Results: Bidding Offers

\begin{tabular}{|c|c|c|c|}
\hline \multirow{3}{*}{$\begin{array}{l}\text { Dependent variable: } \\
\text { Mean outcome: }\end{array}$} & \multicolumn{3}{|c|}{ Bidding rebate } \\
\hline & \multicolumn{3}{|c|}{ OLS regressions } \\
\hline & 1 & 2 & 3 \\
\hline Optional & $\begin{array}{l}0.224^{\star *} \\
(0.099)\end{array}$ & $\begin{array}{l}0.316^{\star * *} \\
(0.100)\end{array}$ & $\begin{array}{l}0.403^{\star * *} \\
(0.109)\end{array}$ \\
\hline log(Reserve price) & $\begin{array}{c}0.104 \\
(0.065)\end{array}$ & $\begin{array}{c}0.143^{\star} \\
(0.076)\end{array}$ & $\begin{array}{c}0.122 \\
(0.088)\end{array}$ \\
\hline log(Expected duration) & $\begin{array}{c}-0.097 \\
(0.084)\end{array}$ & $\begin{array}{c}-0.093 \\
(0.094)\end{array}$ & $\begin{array}{r}-0.235^{\star} \\
(0.128)\end{array}$ \\
\hline $\log$ (No. participants) & $\begin{array}{l}1.242^{\star * \star} \\
(0.137)\end{array}$ & $\begin{array}{l}1.340^{\star * *} \\
(0.153)\end{array}$ & $\begin{array}{l}1.234^{\text {***}} \\
(0.199)\end{array}$ \\
\hline $\log (1+$ Backlog $)$ & $\begin{array}{c}-0.065 \\
(0.063)\end{array}$ & $\begin{array}{c}0.035 \\
(0.085)\end{array}$ & $\begin{array}{c}-0.225 \\
(0.213)\end{array}$ \\
\hline log(Distance) & $\begin{array}{c}0.007 \\
(0.029)\end{array}$ & & \\
\hline Category of work dummy & YES & YES & YES \\
\hline Type of auction dummy & YES & YES & YES \\
\hline Firm size dummy & YES & NO & $\mathrm{NO}$ \\
\hline Firm-fixed effects & NO & YES & NO \\
\hline Firm-year-fixed effects & NO & NO & YES \\
\hline Year dummy & YES & YES & NO \\
\hline Observations & 13,331 & 9961 & 6280 \\
\hline R-squared & 0.520 & 0.562 & 0.575 \\
\hline
\end{tabular}

Note: See Appendix A for the definition of the variables.

Robust standard errors clustered at firm-level in parentheses.

Inference: ${ }^{\star * *} p<0.01,{ }^{* *} p<0.05,{ }^{*} p<0.1$.

authors argue that the decision to outsource involves a trade-off between lower production costs and higher monitoring costs. Thus, the supplier opts to use subcontractors when the efficiency gains from lower production costs are greater than the loss of control resulting from the higher monitoring costs of outsourcing. In our setting, monitoring costs are lower for optional subcontracting than for mandatory subcontracting, as the work with optional subcontracting is delegated to similarly qualified firms. $^{25}$

For the effects of bargaining power, Grossman and Helpman (2002) investigate how the distribution of bargaining power between the subcontractor and the supplier affects the viability of outsourcing. Their model shows that a generic task - as opposed to a specific one - enhances outside options, which improves the task producer's bargaining power. Similarly,

25. Riordan and Sappington (1987) provide a two-stage production model in which costs are observable only by the producing party. The information asymmetry between parties and the correlation between first- and second-stage costs determine the principal's optimal choice in the organization of task productions. 
in our setting, a firm that can choose to delegate part of the work (i.e., optional subcontracting) is endowed with an outside option that enhances its bargaining power in outsourcing. This outside option is not present in the case of mandatory subcontracting.

Our results are also consistent with the study by Lafontaine and Slade (2008) regarding firm boundaries and the effects of rules. In their setting, the authors find that voluntary arrangements among firms have a positive impact on market performance (i.e., lowering both firm costs and consumer prices), while government-mandated arrangements systematically have a negative impact on market performance.

For other firm characteristics, the model specification in column 1 of Table 4 includes dummy variables for firm size, the distance between the firm's location and CA, and a measure of the firm's backlog. The model in column 2 includes dummy variables for firm-fixed effects, which enables us to control for firm characteristics that do not vary over time. Moreover, the model in column 3 includes dummy variables for firm-year-fixed effects, which aim to capture a firm's characteristics (e.g., its size, financial position, and productivity) in any given year. The use of firm-fixed effects in the model also allows us to exclude from our sample consortia and firms that always or never had all of the necessary qualifications, and thus, to only concentrate on the bidding firms that were fully qualified for some auctions and partially qualified for others. Concentrating on such firms is important for two reasons. First, to avoid any biases in our estimates that might have stemmed from the inclusion of consortia in our sample (with the corresponding assumption regarding that these consortia had all the necessary qualifications). And second, and more importantly, to support our inference that the overall results are not influenced by firms that always or never had all of the required qualifications. This approach allows us to exploit the within-firm (or within-firm-year) variations in subcontracting status.

Our estimates of the other control variables in the model specifications are comparable to the results obtained in previous empirical studies on the awarding of public procurement contracts. It is hardly surprising that rebates are positively influenced by the size of a project and the number of participants, and negatively influenced by the expected duration of the work (the size and duration measures are both calculated by the CA engineers and are known by the firms before they place their bids). ${ }^{26}$

26. In the United States, Bajari et al. (2009) show that having more firms competing in an auction reduces bidding prices. Their finding is based on a dataset of contracts awarded by private authorities in the building construction industry in northern California from 1995 to 2001. Similarly, based on a sample of Italian public procurement auctions, Bucciol et al. (2013) finds that a larger number of bidders increases the amount of the winning bidder's rebate. Our results confirm the positive (although weakly significant) effect of the reserve price on the rebates offered, as also reported by Coviello and Gagliarducci (2010) and Decarolis (2009). Note that, in our estimates, the results for the controls for backlog and distance between the bidder and CA are not statistically significant. 


\subsection{Robustness Checks}

A first concern regarding our estimates has to do with the influence of extreme bids. In fact, it may be that outlying bids drive the estimation of the coefficient for our Optional variable of interest. We address this concern by using a robust regression approach (iteratively reweighted least squares, [IRLS]) that iteratively assigns a lower weight to outlying observations. As shown in Table 5, column 1, the estimated coefficient of the optional subcontracting status is positive and statistically significant, thus confirming the previous estimates.

A further concern is related to the likelihood that the estimated difference in offered bids between firms in optional subcontracting positions and firms in mandatory subcontracting positions is driven by very different rebate distributions across auctions. In fact, the number of participants and their bids vary across auctions, resulting in a different rebate distribution for each auction. Even if we control for several characteristics of the auction in the model specification, we may not fully capture these differences.

The average bid auction adopted in order to award the public procurement contracts enables us to identify different areas in the distribution of the bidding firms' rebates. In particular, we distinguish an area around the winning rebate as follows. The winning offer in each average bid auction is between the mean rebate (A1) and the rebate corresponding to the 90th percentile of the distribution ("area A", see Figure B1, upper panel, in Appendix B). In the average bid auctions combined with a lottery, the winning offer is between lowest possible winning threshold (A3) and the rebate at the 90th percentile of the distribution ("area A", see Figure B1, lower panel, in Appendix B). We focus on the "area A" of the auctionspecific distribution of the rebates and check whether the previously estimated difference holds. We perform this check because one might suspect that our results are driven by the fact that bidders subject to mandatory subcontracting tend to offer particularly small rebates; that is, those bids on the left-hand side of the distribution. If this were true, subcontracting status may not be the only difference between the two types of bidders. There may be other differences related to the firms' productivity and technology. Moreover, firms bidding in a mandatory subcontracting position would not be competitive enough to win the auction and they may take part in auctions for collusive purposes; that is, to favor a given bidder (or a group of bidders).

Therefore, after ensuring that the subcontracting position is not a significant determinant of the bidders' likelihood to offer a bid in "area A" of each auction distribution, ${ }^{27}$ we concentrate our analysis on "area A" of each auction distribution and we nonetheless find that the difference in the

27. Note that in terms of distance from the winning bid, firms in both optional and mandatory subcontracting positions offer, on average, rebates lower than the winning rebate $(-0.812$ and -0.617 percentage points, respectively). 


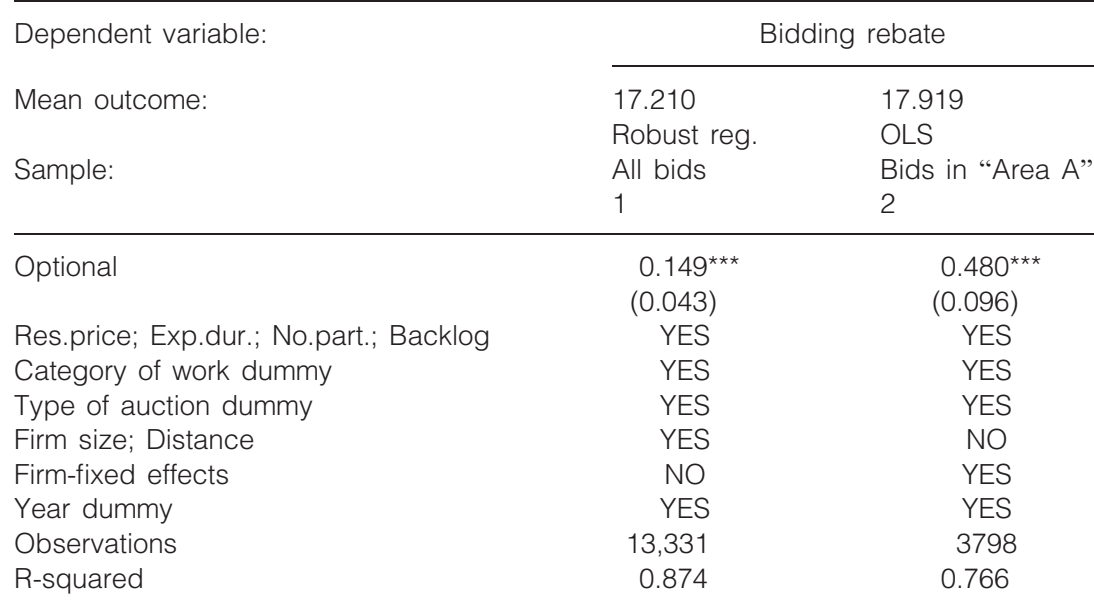

Note: See Appendix A for the definitions of the variables.

Standard errors are in parentheses. In column 2, robust standard errors are clustered at the firm-level. Inference: ${ }^{* \star} p<0.01,{ }^{\star *} p<0.05,{ }^{*} p<0.1$.

rebates offered between firms in the two different subcontracting positions persists and is statistically significant (Table 5, column 2).

\section{Analysis of the Winning Offers}

This section analyzes whether the more aggressive bids offered by firms that can choose whether or not to subcontract result from the expected potential advantage of outsourcing or the reluctance of such firms to use subcontractors. To ascertain whether the firms' optional subcontracting status is associated with lower prices, we examine the winning firms that could opt for outsourcing and actually used subcontractors to complete part of the awarded projects.

With this aim, we now consider two samples: one consists of 220 winning bids drawn from the sample of auctions held by the Regional Government of Valle d'Aosta; ${ }^{28}$ the other (which served to test the robustness of our estimates) includes winning bids in 449 auctions held by several CAs in Valle d'Aosta between 2000 and 2009. For the latter sample of auctions, we only know the characteristics of the winning firms and their rebates; we have no information on the bids of the other

28. This sample is extracted from the 269 auctions held by the Regional Government of Valle d'Aosta. For 49 of these auctions, we do not have full details regarding the number of subcontractors and the value of the subcontracted work, or we do not have information to determine the subcontracting position of the winning firm. See the upper panel in Table 6 for the summary statistics for this sample. 
participants. $^{29}$ For each project, we obtain information from the AVCP dataset on the extent of subcontracting and the number (and ID) of the subcontractors that were used by the winning firm (see the summary statistics in Table 6).

The descriptive statistics for the sample of winning rebates in the Regional Government's auctions indicate that approximately $85.0 \%$ of suppliers actually subcontracted at least part of the work and approximately $88.2 \%$ of the firms had an optional subcontracting status. Also note that, excluding consortia, firms in optional subcontracting positions that did subcontract outsourced a smaller proportion of their project's value (approximately 259,000 euros, on average) than firms in mandatory subcontracting positions (approximately 275,000 euros, on average). Similarly, winning firms that had the option to subcontract outsourced to a smaller number of subcontractors (1.8) than firms that were required to outsource (2.5), as well as the firms belonging to a consortium (2.1).

\subsection{Estimation Results}

To study the rebates offered by winning firms that actually engage in subcontracting, in our model specification, we include the interaction between the firm's optional subcontracting status and the variable indicating the firm's actual use of subcontracting (Sub*Optional). Because Italian regulation prohibits a firm in a mandatory subcontracting position from not subcontracting, it is necessary to exclude $(S u b)$ from the set of dummy variables in the model.

The results are presented in Table 7 columns 1 and 3, and show that the (Sub*Optional) interaction term is positive and statistically significant, while the (Optional) coefficient is positive (and statistically significant in column 3). This indicates that the effect on the winning rebates related to a mandatory subcontracting position is negative and that the effect related to an optional subcontracting position is especially large when the firm actually subcontracts. ${ }^{30}$

29. The summary statistics for this sample are presented in the lower panel in Table 6 . In this sample, $58.4 \%$ of the projects were for the Regional Government, $34.5 \%$ were for municipalities, and the remainder was for other local public authorities (e.g., territorial associations for mountainous areas). Note that for the auctions appearing only in this sample, we are not able to distinguish between $\mathrm{ABA}$ and $\mathrm{ABA}+$ lottery awarding mechanisms. Note also that the smaller set of winning offers (220) for contracts awarded by the Regional Government is a sub-sample of this larger sample (449).

30. To deal with any outliers, we use robust regressions (IRLS), which iteratively assign a lower weight to deviant observations. The winning prices are generally distributed in the same way in the two samples; however, when the distribution of the winning prices is compared with the distribution of all prices offered for contracts with the Regional Government of Valle d'Aosta, the presence of outlying observations seems to have more weight in the distribution of the winning price. 
Table 6. Descriptive Statistics: Winning Offers and Contract Characteristics

Procurement projects issued by Valle d'Aosta Regional Government

\begin{tabular}{llllll}
\hline Variable & Obs. & Mean & St.Dev. & Min & Max \\
Winning rebate (\%) & 220 & 17.222 & 4.260 & 3.620 & 31.990 \\
Sub & 220 & 0.850 & 0.358 & 0 & 1 \\
Optional & 220 & 0.882 & 0.324 & 0 & 1 \\
No. of subcontractors & 220 & 1.645 & 1.527 & 0 & 11 \\
Value of subcontracts (euros) & 220 & 244543.9 & 297106.3 & 0 & 1800620 \\
Bidder-Subcontractor & 220 & 0.409 & 0.493 & 0 & 1 \\
Reserve price (euros) & 220 & 1137356 & 894343.5 & 155526.3 & 5267860 \\
No. of participants & 220 & 57.005 & 32.604 & 3 & 155 \\
Expected duration (days) & 220 & 310.145 & 155.766 & 79 & 899 \\
Road works & 220 & 0.341 & 0.475 & 0 & 1 \\
River and hydraulic works & 220 & 0.327 & 0.470 & 0 & 1 \\
Buildings & 220 & 0.150 & 0.358 & 0 & 1 \\
\hline
\end{tabular}

Procurement projects issued within the borders of Valle d'Aosta by several CAs

\begin{tabular}{llllll}
\hline Winning rebate (\%) & 449 & 16.068 & 4.717 & 1.900 & 36.639 \\
Sub & 449 & 0.788 & 0.409 & 0 & 1 \\
Optional & 449 & 0.768 & 0.422 & 0 & 1 \\
No. of subcontractors & 449 & 1.724 & 1.977 & 0 & 17 \\
Value of subcontracts (euros) & 449 & 213693.2 & 329375.1 & 0 & 3256000 \\
Reserve price (euros) & 449 & 973631.8 & 884015.4 & 151457.4 & 6180000 \\
No. of participants & 449 & 44.512 & 32.669 & 3 & 159 \\
Expected duration (days) & 449 & 301.987 & 170.973 & 59 & 977 \\
Road works & 449 & 0.336 & 0.473 & 0 & 1 \\
Buildings & 449 & 0.203 & 0.402 & 0 & 1 \\
River and hydraulic works & 449 & 0.194 & 0.396 & 0 & 1 \\
\hline
\end{tabular}

Note: See Appendix A for the definition of the variables.

These empirical findings are in line with Spiegel's (1993) theoretical results on horizontal subcontracting, which indicate that this form of outsourcing allows firms to improve their production efficiency and increases social welfare for a large set of parameters in his model.

In our setting, horizontal subcontracting corresponds to optional subcontracting and firms engaging in optional subcontracting can indeed offer higher rebates than firms engaging in mandatory subcontracting (a form of vertical outsourcing). In particular, our estimates indicate that the option to subcontract induces firms to outsource only when it is profitable. The option to outsource, in turn, gives the firm a stronger bargaining position than the obligation to outsource part of the project. This conclusion is confirmed by the results in Table 7, columns 2 and 4, where the auction samples are restricted to contracts where at least part of the project was handled by subcontractors (i.e., the focus in these columns is limited to projects involved in subcontracting). Again, the coefficient estimated for the Optional variable is positive and statistically significant, indicating that firms in an optional subcontracting position won the 
Table 7. Estimation Results: Winning Offers

\begin{tabular}{|c|c|c|c|c|}
\hline \multirow{4}{*}{$\begin{array}{l}\text { Dependent variable: } \\
\text { Mean outcome: } \\
\text { CA: } \\
\text { Sample: }\end{array}$} & \multicolumn{4}{|c|}{ Winning rebate } \\
\hline & 17.222 & \multicolumn{3}{|c|}{ Robust regressions } \\
\hline & \multicolumn{2}{|c|}{ Regional Government } & \multicolumn{2}{|c|}{ Several CAs } \\
\hline & $\begin{array}{l}\text { Full } \\
1\end{array}$ & $\begin{array}{l}\text { Only sub } \\
2\end{array}$ & $\begin{array}{l}\text { Full } \\
3\end{array}$ & $\begin{array}{l}\text { Only sub } \\
4\end{array}$ \\
\hline Optional & $\begin{array}{c}0.408 \\
(0.370)\end{array}$ & $\begin{array}{l}1.278^{* * *} \\
(0.305)\end{array}$ & $\begin{array}{c}0.627^{*} \\
(0.321)\end{array}$ & $\begin{array}{l}1.279^{\star * *} \\
(0.264)\end{array}$ \\
\hline Sub*Optional & $\begin{array}{l}0.764^{\star * \star} \\
(0.260)\end{array}$ & & $\begin{array}{c}0.500^{*} \\
(0.264)\end{array}$ & \\
\hline log (Value of subcontracts) & & $\begin{array}{c}0.198 \\
(0.149)\end{array}$ & & $\begin{array}{c}0.279^{*} \\
(0.145)\end{array}$ \\
\hline $\log$ (No. subcontractors) & & $\begin{array}{c}0.049 \\
(0.190)\end{array}$ & & $\begin{array}{c}0.027 \\
(0.204)\end{array}$ \\
\hline Bidder-subcontractor & & $\begin{array}{c}-0.198 \\
(0.201)\end{array}$ & & \\
\hline Res.price; Exp.dur.; No.part.; Backlog & YES & YES & YES & YES \\
\hline Category of work dummy & YES & YES & YES & YES \\
\hline Type of auction dummy & YES & YES & NO & NO \\
\hline Type of CA dummy & NO & NO & YES & YES \\
\hline Firm size; Distance & YES & YES & YES & YES \\
\hline Year dummy & YES & YES & YES & YES \\
\hline Observations & 220 & 187 & 449 & 354 \\
\hline
\end{tabular}

Note: See Appendix A for the definitions of the variables.

Standard errors are in parentheses.

Inference: ${ }^{\star \star \star} p<0.01,{ }^{\star *} p<0.05,{ }^{*} p<0.1$.

contract with a discount approximately 1.3 percentage points higher than firms in a mandatory subcontracting position. This value corresponds to approximately $7.5 \%$ of the average winning percentage discount observed in our data.

In the estimated model specifications in Table 7, columns 2 and 4, we include two further variables - the number of subcontractors (No. subcontractors) and the value of the subcontracts (Value of subcontracts) - to investigate whether these variables affect the bids offered and influence the validity of our findings. The estimated coefficient of the variable for the number of subcontractors is positive and not statistically significant, ${ }^{31}$

31. Differently from the setting investigated by Gil and Marion (2013), we rarely observe repeated interactions between contractors and subcontractors in the public procurement market of Valle D'Aosta (on average, they interacted only 1.2 times in a decade). Note that the environment analyzed in Gil and Marion's paper is characterized by features that potentially give rise to relational intertemporal incentives between contractors and subcontractors: the subcontractors do not have to be strictly qualified and should be indicated when the bid is made; and the contractors benefit from having a larger degree of discretion in the outsourcing choice. 
while the estimated coefficient of the variable for the value of subcontracts is positive, but only statistically significant in the sample of auctions issued by several CAs in the region. ${ }^{32}$

\section{Extensions}

Thus far, our results indicate that the subcontracting status is strongly associated with the rebates offered. We interpret this finding to indicate that firms discount their outsourcing position in their bids. Considering the procurement agencies' interest, which focuses also on other performance outcomes aside from gathering competitive bids, it is worthwhile to examine whether the two subcontracting positions are associated with different ex-post performances. To empirically test whether there is a relationship between subcontracting position and ex-post performance, we use data for the probability of time and cost overrun in the execution of a project. We define time overruns as the probability of completing the project after the expected (contracted) deadline and cost overruns as the probability that the final cost of the project is greater than the winning bid.

A priori, the effect of the subcontracting position on ex-post performance is unclear. On the one hand, we might expect that the more aggressive bidding behavior of optional subcontracting firms who offer higher rebates would result in worse ex-post performance as suppliers try to recover some mark-up during the executional phase of the project. On the other hand, mandatory subcontracting firms may not have sufficiently discounted their asymmetric information and lower bargaining power positions within their offers, so they may incur additional costs during the contract's execution.

In our data, we observe a high probability of time and cost overruns. In fact, time and cost overruns occurred respectively in $91.8 \%$ and in $84.5 \%$ of the projects for the Regional Government of Valle d'Aosta, while time and cost overruns occurred respectively in $93.1 \%$ and in $86.6 \%$ of projects

32. Note that, in column 2 of Table 7, the coefficient for the Bidder-subcontractor variable (concerning the presence of at least one subcontractor who also participated as a bidder in the same auction) is not statistically significant. As recently studied by Marion (2013), when a supplier outsources part of the work to a subcontractor who has participated in the same auction (i.e., a rival in the auction) and when there is an ex-ante agreement between the two, maximizing his effort to win the auction may not be optimal for the subcontractor because the opportunity to work as a subcontractor may be more profitable. It is worth stressing here that in Italian public procurement, bidders should not commit to engage in a subcontracting relationship with a particular firm at the auction stage. Indeed, bidders do not have to indicate the names of the subcontractors in their offers. This setting reduces the likelihood that firms will make ex-ante agreements and thus, such agreements may not have any influence on their rivals' costs. 
Table 8. Estimation Results: Ex-Post Performance

\begin{tabular}{|c|c|c|c|c|c|}
\hline \multirow[t]{2}{*}{ Dependent variable: } & \multicolumn{5}{|c|}{ Probability of: } \\
\hline & $\begin{array}{l}\text { Time } \\
\text { overrun } \\
0.894\end{array}$ & $\begin{array}{l}\text { Cost } \\
\text { overrun } \\
0.834\end{array}$ & $\begin{array}{l}\text { Time } \\
\text { overrun } \\
0.915\end{array}$ & $\begin{array}{l}\text { Cost } \\
\text { overrun } \\
0.869\end{array}$ & $\begin{array}{l}\text { rebate } \\
>\text { Win } \\
0.349\end{array}$ \\
\hline Mean outcome: & \multicolumn{5}{|c|}{ Probit regressions } \\
\hline \multirow[t]{2}{*}{ CA: } & \multicolumn{2}{|c|}{ Regional Gov. } & \multicolumn{2}{|c|}{ Several CAs } & \multirow{2}{*}{$\begin{array}{l}\text { Regional } \\
\text { Gov. } \\
5\end{array}$} \\
\hline & 1 & 2 & 3 & 4 & \\
\hline Optional & $\begin{array}{r}-0.757 \\
(0.593)\end{array}$ & $\begin{array}{r}-0.999 \\
(0.718)\end{array}$ & $\begin{array}{c}0.097 \\
(0.307)\end{array}$ & $\begin{array}{c}-0.106 \\
(0.296)\end{array}$ & $\begin{array}{c}0.028 \\
(0.042)\end{array}$ \\
\hline Sub*Optional & $\begin{array}{c}0.215 \\
(0.417)\end{array}$ & $\begin{array}{c}0.113 \\
(0.356)\end{array}$ & $\begin{array}{c}-0.243 \\
(0.275)\end{array}$ & $\begin{array}{c}-0.003 \\
(0.245)\end{array}$ & \\
\hline Res.price; Exp.dur.; No.part. & YES & YES & YES & YES & YES \\
\hline Category of work dummy & YES & YES & YES & YES & YES \\
\hline Type of auction dummy & YES & YES & NO & NO & YES \\
\hline Type of CA dummy & NO & NO & YES & YES & NO \\
\hline Firm size; Backlog; Distance & YES & YES & YES & YES & YES \\
\hline Year dummy & YES & YES & YES & YES & YES \\
\hline Observations & 170 & 199 & 355 & 404 & 13,331 \\
\hline
\end{tabular}

Note: See Appendix A for the definitions of the variables.

Robust standard errors clustered at the firm-level are presented in parentheses.

Inference: ${ }^{* *} p<0.01,{ }^{* *} p<0.05,{ }^{*} p<0.1$.

awarded by several CAs in the Valle d'Aosta region. We use data for both samples of projects to test a relationship between firm's subcontracting position and the probability of time and cost overruns.

The results in Table 8, columns 1-4, do not indicate a clear relationship between a firm's subcontracting position and the probability of time and cost overrun. ${ }^{33}$ Firstly, the estimated coefficients for (Optional) and (Sub*Optional) are not statistically significant. Secondly, the signs of the coefficients estimated for the sample of auctions issued by the Regional Government and the sample of auctions issued by several CAs in the region are mixed.

When we focus on the sample of the Regional Government (columns 1 and 2), we find that the predicted probability of time overruns, computed at the mean values of the other regressors, is the highest for firms in a mandatory subcontracting position $(98.3 \%)$. This probability is higher for firms in an optional subcontracting position that do subcontract $(94.3 \%)$ than for firms that do not subcontract (91.4\%). Similarly, we find that the predicted probability of cost overruns at the means is the highest for firms in a mandatory subcontracting position $(97.9 \%)$, while this probability is

33. In the probit regressions, perfectly predicted observations have been dropped. 
higher for firms in an optional subcontracting position that do subcontract $(87.6 \%)$ than for firms that do not subcontract $(85.2 \%) .{ }^{34}$ However, when we focus on the sample that includes also contracts issued by other CAs (columns 3 and 4), the estimation results show that the optional subcontracting firms that do subcontract have the lowest predicted probability of cost and time overruns (computed at the mean values of the other regressors).

This unclear relationship is also confirmed in Table 8, column 5, where we estimate the probability of very high rebates, which could be associated with a higher risk of holding up the buyer ex-post. The estimation results show that optional subcontracting firms do not have a significantly different probability of offering rebates that are higher than the winning bid. In other words, our data do not provide empirical evidence supporting the hypothesis that high rebates are associated with ex-post hold-up in the performance of the contract.

\section{Conclusion}

We empirically investigate public procurement in Italy, where the existing regulations on the firms' pre-qualifications for performing public works contracts determine two different subcontracting positions: (i) the contractor is fully qualified and may choose to either subcontract part of the contract or to complete the work on his own (optional subcontracting); or (ii) the contractor is partially qualified and is obliged to subcontract part of the work to a qualified firm (mandatory subcontracting).

We examine the two subcontracting positions by analyzing data on the auctions for public works and the bidders' characteristics. We find that bidders in an optional subcontracting position offer lower prices (i.e., higher rebates on the reserve prices set by the contracting authority awarding the contract) than those in a mandatory subcontracting position.

Our findings are confirmed by different estimation and robustness tests. In particular, when we focus only on the bids made by auction winners that subsequently subcontracted part of the contract, we find that the costs of completing the contracts are lower when firms actually engage in optional subcontracting than when firms are mandated to engage in

34. Note that, the average predicted probability (not computed at the mean values of the other regressors) of time overruns for the group of firms in a mandatory subcontracting position is $90.7 \%$, in a optional subcontracting position that do subcontract is $89.2 \%$, and in optional subcontracting position that do not subcontract is $90.0 \%$. The average predicted probability of cost overruns for the group of firms in a mandatory subcontracting position is $95.2 \%$, in a optional subcontracting position that do subcontract is $82.8 \%$, and in optional subcontracting position that do not subcontract is $75.9 \%$. 
subcontracting. Moreover, we find no significant differences in contract performance (i.e., the probability of cost and time overruns) between the two subcontracting positions.

We interpret these findings as follows. Having the option to use subcontractors induces firms to do so only when subcontracting part of the work is profitable and when it puts them in a stronger position regarding information asymmetry and bargaining power. Firms obliged by regulation to engage in mandatory subcontracting lack these advantages and include the higher expected costs of outsourcing in their bids.

Our results are consistent with those from an empirical survey of vertical arrangements by Lafontaine and Slade (2008). Both the findings of these authors and our empirical results indicate that voluntary arrangements tend to improve, while imposed arrangements tend to worsen market performance. This has interesting policy implications for public procurement, a setting in which pre-qualification rules to prevent lowquality procurement transactions are often adopted. All in all, our results suggest that limiting the discretion of firms in terms of their supply-chain choices represents a cost (i.e., higher price) in the public procurement process. A way to reduce this cost according to our context could be to define relatively broader categories of work for firms' qualifications. In so doing the winning firms would be fully qualified more often and thus would exert their more efficient discretional choices for subcontracting. Contextually, this broader regulatory design should be coupled with both the adoption of reputational criteria in the awarding of contracts (i.e., the suppliers' past performance) and the entitlement of power to the procurement authorities to disqualify any unsuitable firms (Spagnolo 2012). This would counterbalance the potential reduction in quality associated with the contractors as a consequence of the more leniant pre-qualification screenings. Future research is still needed to understand this trade-off.

\section{Appendix A}

Variables, Definitions and Abbreviations

Rebate (or percentage of the price reduction or discount). The price cut offered by participants in an auction, expressed as a percentage of the auction's reserve price.

Optional. A dummy variable taking a value of 1 if the firm can choose whether to horizontally subcontract part of the contracted work; this firm is fully qualified to complete the project alone, but it can opt to subcontract part of the work to firms with similar qualifications. The dummy takes a value of 0 if the firm is required by law to subcontract part of the work that it is not qualified to perform. 
Mandatory. A dummy variable taking a value of 1 if the firm is required by law to subcontract part of the work; this firm does not have all the qualifications to complete the project, and it is required by law to subcontract the work for which it is not qualified to perform to firms with the required qualifications. The dummy takes a value of 0 if the firm (being fully qualified to handle the work) can choose whether to subcontract part of the work.

Reserve price. The auction's starting value (in euros) decided by the contracting authority [CA]. All the projects considered in this analysis had a reserve price higher than 150,000 euros.

Expected duration. The expected duration of the work (in days), decided by the CA.

No. of participants. The number of bidders participating in an auction.

Firm size. A set of dummy variables that are used as proxies for the size of the bidding firms. Because we do not have data on the number of firms' employees or their total assets, we construct proxies based on the type of business entity (there is a positive correlation between the type of business entity and the size of the Italian firms). In particular, our proxies are defined as: Small (one-man businesses, limited and ordinary partnerships); Medium (limited liability companies); or Large + cooperatives (public corporations and cooperatives).

Distance. It is a proxy for the distance between the firm and the project. Because we do not have information for the exact location of the project and of the firm, it is defined as the distance in kilometers from the capital city of the province in which the firm is located and the city of Aosta (which is the capital city of the single-province region of Valle d'Aosta and where the CA is located). We assign a distance of $30 \mathrm{~km}$ to firms located in Valle d'Aosta.

Backlog. A proxy for the firms' capacity constraints, defined as the number of pending projects (considering also public procurement works tendered in other Italian regions) the firm has at the date of bidding.

Consortia. A dummy variable taking a value of 1 when it refers to a temporary association of firms, and 0 otherwise. Firms can join forces, pool their qualifications and form a consortium to participate in a given auction, so we assume that the variable Optional takes a value of 1 for consortia. 
Type of auction. A set of dummy variables describing the auction mechanism.

$A B A$ is an average bid auction defined as follows. Given the distribution of all bids received in an auction, a first average (A1) is computed by averaging all bids except those located in the first and last deciles. A second average (A2) is then computed by averaging all of the bids above A1 (again, excluding those bids located in the last decile). The winning bid is the one immediately below A2 (see Figure B1, upper panel, in Appendix B). If there are fewer than ten bidders, the lowest and highest bid is not considered to compute the first average (A1). If there are fewer than five bidders, the project is awarded to the firm that has offered the highest rebate.

$A B A+$ lottery is an average bid auction defined as follows. Given A2 computed as above, a random integer $\mathrm{R}$ between 1 and 9 is extracted. The R-th number among the nine equidistant numbers between the bid just above the first decile and the bid just below A2 is averaged with A2 to obtain the winning threshold. The winning bid is the bid immediately above this winning threshold. We define A3 as the winning threshold that results when $\mathrm{R}=1$ (see Figure $\mathrm{B} 1$, lower panel, in Appendix B).

Category of work. A set of dummy variables representing the main category of work in a project (e.g., road works, buildings, hydraulic works, etc.).

Sub. A dummy variable taking a value of 1 if the winning firm subcontracts part of the work in a project, and 0 otherwise.

No. of subcontractors. The number of subcontractors working on a project.

Value of subcontract. The value (in euros) of the subcontracts for a project.

Bidder-subcontractor. A dummy variable that takes a value of 1 if, for a given contract, at least one subcontractor participated as a bidder in the auction. It takes a value of 0 otherwise.

Type of CA. A set of dummy variables representing the type of contracting authority auctioning the work (e.g., regional or local governments, public health authorities, etc.). 


\section{Appendix B}

\section{Average bid auction}

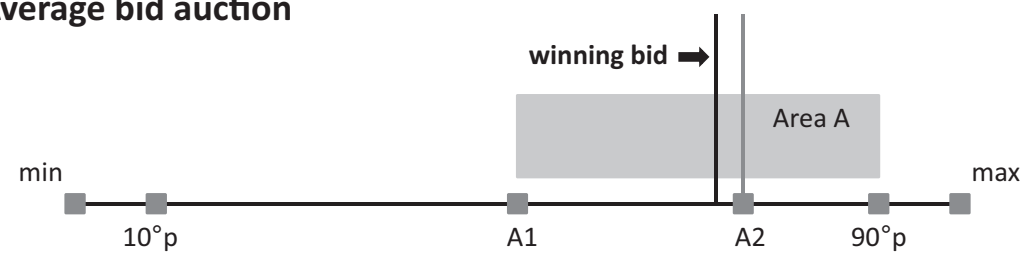

\section{Average bid auction + lottery}

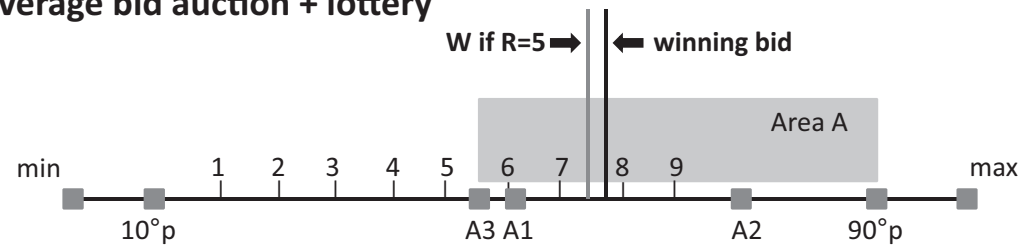

Figure B1. Types of auction.

\section{References}

Albano, G., M. Bianchi, and G. Spagnolo. 2006. "Bid Average Methods in procurement," 1-2 Rivista di Politica Economica 41-62.

Athey, S., D. Coey, and J. Levin. 2013. "Set-Asides and Subsidies in Auctions," 5 American Economic Journal: Microeconomics 1-27.

Bajari, P., S. Houghton, and S. Tadelis. 2014. "Bidding for Incomplete Contracts: an Empirical Analysis of Adaptation Costs," 104 American Economic Review 1288-319.

Bajari, P., R. McMillan, and S. Tadelis. 2009. "Auctions versus Negotiations in Procurement: an Empirical Analysis," 25 Journal of Law, Economics and Organization 372-99.

Bucciol, A., O. Chillemi, and G. Palazzi. 2013. "Cost Overrun and Auction Format in Small Size Public Works," 30 European Journal of Political Economy 35-42.

Chang, W.S., B. Chen, and T.C. Salmon. 2013. "An Investigation of the Average Bid Mechanism for Procurement Auctions," Management Science forthcoming.

Coviello, D., and S. Gagliarducci. 2010. "Building Political Collusion: Evidence from Procurement Auctions," IZA Discussion Papers 4939, Institute for the Study of Labor (IZA).

Decarolis, F. 2009. "When the Highest Bidder Loses the Auction: Theory and Evidence from Public Procurement," Economic working papers 717, Bank of Italy, Economic Research Department.

. 2013. "Awarding Price, Contract Performance and Bids Screening: Evidence from Procurement Auctions," 6 American Economic Journal: Applied Economics 108-32.

De Silva, D.G., T. Dunne, G. Kosmopoulou, and C. Lamarche. 2012. "Disadvantaged Business Enterprise Goals in Government Procurement Contracting: An Analysis of Bidding Behavior and Costs," 4 International Journal of Industrial Organization 377-88.

Galavotti, S., L. Moretti, and P. Valbonesi. 2014. "Sophisticated Bidders in Beauty Contest Auctions," Marco Fanno Working Paper 187, Department of Economics and Management, University of Padova. 
Gale, I.L., D.B. Hausch, and M. Stegeman. 2000. "Sequential Procurement with Subcontracting," 41 International Economic Review 989-1020.

Gil, R., and J. Marion. 2013. "Self-Enforcing Agreements and Relational Contracting: Evidence from California Highway Procurement," 29 Journal of Law, Economics, and Organization 239-77.

Grossman, S., and O. Hart. 1986. "The Costs and Benefits of Ownership: a Theory of Vertical and Lateral Integration," 94 Journal of Political Economy 691-719.

Grossman, G.M., and E. Helpman. 2002. "Integration versus Outsourcing in Industry Equilibrium," 117 Quarterly Journal of Economics 85-120.

Joskow, P.L. 1988. "Asset Specificity and the Structure of Vertical Relationships: Empirical Evidence," 4 Journal of Law, Economics and Organization 95-117.

Kamien, M., and L. Li. 1990. "Subcontracting, Coordination, Flexibility and Production Smoothing in Aggregate Planning," 36 Management Science 1352-63.

Kamien, M., L. Li, and D. Samet. 1989. "Bertrand Competition with Subcontracting," 20 Rand Journal of Economics 553-67.

Kogut, B., and U. Zander. 1992. "Knowledge of the Firm, Combinative Capabilities, and the Replication of Technology," 3 Organization Science 383-97.

- 1996. "What Firms Do? Coordination, Identity, and Learning," 7 Organization Science 502-18.

Krasnokutskaya, E., and K. Seim. 2011. "Bid Preference Programs and Participation in Highway Procurement Auctions," 101 American Economic Review 2653-86.

Lafontaine, F., and M. Slade. 2007. "Vertical Integration and Firm Boundaries: The Evidence," 45 Journal of Economic Literature 629-85.

_. 2008. "Exclusive Contracts and Vertical Restraints: Empirical Evidence and Public Policy," in P. Buccirossi, ed., Hanbook of Antistrust Economics. 391-414. Cambridge MA: MIT Press.

Lewis, T.R., and D.E.M. Sappington. 1991. "Technological Change and the Boundaries of the Firm," 81 American Economic Review 887-900.

Lewis, G., and P. Bajari. 2011. "Procurement Contracting with Time Incentives: Theory and Evidence," 126 Quarterly Journal of Economics 1173-211.

Macher, J.T. 2006. "Technological Development and the Boundaries of the Firm: A Knowledge-Based Examination in Semiconductor Manufacturing," 52 Management Science 826-43.

Marion, J. 2007. "Are Bid Preferences Benign? The effect of Small Business Subsidies in Highway Procurement Auctions," 91 Journal of Public Economics 1591-624.

- 2009. "How Costly is Affirmative Auction? Government Contracting and California's Proposition 209," 91 Review of Economics and Statistics 503-22.

- 2013. "Sourcing from the Enemy: Horizontal Subcontracting in Highway Procurement,"The Journal of Industrial Economics forthcoming.

Miller, D. 2014. "Subcontracting and Competitive Bidding on Incomplete Procurement Contracts," 45 The Rand Journal of Economics 705-46.

Novak, S., and S. Stern. 2008. "How Does Outsourcing Affect Performance Dynamics? Evidence from the Automobile Industry," 54 Management Science 1963-79.

OECD. 2007. Integrity in Public Procurement; available at: www.oecd.org/development/ aideffectiveness/38588964.pdf.

Olivares, M., G.Y. Weintraub, R. Epstein, and D. Yung. 2012. "Combinatorial Auctions for Procurement: An Empirical Study of the Chilean School Meals Auction," 58 Management Science 1458-81.

Quinn, J.B., and F.G. Hilmer. 1994. "Strategic Outsourcing," Summer Sloan Management Review 43-55.

Riordan, M., and D. Sappington. 1987. "Information, Incentives, and Organizational Mode," 102 Quarterly Journal of Economics 243-264.

Spagnolo, G. 2012. "Reputation, Competition, and Entry in Procurement," 30 International Journal of Industrial Organization 291-6.

Spiegel, Y. 1993. "Horizontal Subcontracting," 24 Rand Journal of Economics 570-90. 
Van Mieghem, J.A. 1999. "Coordinating Investment, Production and Subcontracting," 45 Management Science 954-71.

Wan, Z., and D.R. Beil. 2009. "RFQ Auctions with Supplier Qualification Screening," 57 Operational Research 934-49.

Wan, Z., D.R. Beil, and E. Katok. 2012. "When Does It Pay to Delay Supplier Qualification? Theory and Experiment," 58 Management Science 2057-75.

Webster, M., C. Alder, and A.P. Muhlemann. 1997. "Subcontracting within the Supply Chain for Electronics Assembly Manufacture," 17 International Journal of Operations and Production Management 827-84.

Williamson, O. 1971. "The Vertical Integration of Production: Market Failure Considerations," 63 American Economic Review 316-25.

. 1985. The Economic Institutions of Capitalism. New York: The New Press. 